\title{
Intention to Online Shopping on Social Media
}

\author{
Anita Akhirruddin ${ }^{1}$ \\ ${ }^{1}$ Management Study Program, Faculty of Economics and Business \\ Universitas Muhammadiyah Gresik, East Java, Indonesia \\ anitaakhirruddin83@umg.ac.id
}

\begin{abstract}
ABSTRAK
Pertumbuhan belanja online yang tinggi di Indonesia memunculkan banyak situs-situs dan platform onlien yang ada di Indonesia. Salah satu platform online yang banyak digunakan orang di dunia yaitu facebook , menjadi salah satu media jualan online yang sangat ini diminati karena bisa menjangkau lebih banyak orang. Berbelanja online di Facebook selain memberikan keuntungan untuk pihak penjual dan pembeli. Belanja online di Facebook membutuhkan tingkat kepercayaan yang tinggi dari pihak pembeli terkait kualitas produk dan layanan, dan kemudahan dalam memperoleh informasi produk dan pembayaran karena tidak ada jaminan seperti platform online shop seperti shoope, tokopedia, lazada dan lain-lain yang mana sebelum barang diterima pelanggan, maka uang dari pembeli belum bisa dicairkan. Sehingga peneliti tertarik untuk meneliti minat belanja online di situs media sosial facebook. Hasil yang diperoleh adalah variabel kepercayaan, kemudahan transaksi dan kualitas informasi berpengaruh positif terhadap minat beli online di facebook.

Kata kunci: Media Sosial Facebook, Minat Belanja, Online Shop
\end{abstract}

\begin{abstract}
The high growth of online shopping in Indonesia gave rise to many onlien websites and platforms in Indonesia. Facebook, which is one of the social networks that many people use around the world, is one of the online selling media that is in great demand because it can reach more people. Shopping online on Facebook in addition to providing benefits for sellers and buyers. Online shopping on Facebook requires a high level of trust from buyers regarding the quality of products and services, and ease in obtaining product information and payments because there are no guarantees such as online shop platforms such as shoope, tokopedia, lazada and others which before the goods are received by the customer, then the money from the buyer can not be disbursed. So researchers are interested in researching online shopping interests on the social media site facebook. The results obtained are variable trust, ease of transaction and quality of information positively affect the interest in buying online on facebook.
\end{abstract}

Key words: Facebook Social Media, Shopping Interests, Online Shop

\section{INTRODUCTION}

Teaching A population of 260 million people makes Indonesia the country with the highest e-commerce users in the world according to the Global Web Index. As many as $96 \%$ of internet users use it to search for products and services online based on a report published by We Are Social. The growth of ecommerce in the future is expected to continue to grow, especially during the current pandemic which limits people's mobility to leave the house. In 2020, statistical data shows that ecommerce users will reach 168.3 million and 212.2 million in 2023 (https://databoks.katadata.co.id, 2019). This is also emphasized by Sukaris et al., (2019) that technological advances through various media platforms both print, electronic, digital media and social media contribute to the shift in consumer consumption patterns.

When viewed from the increasing number of e-commerce users in Indonesia, it can be seen that there is a tendency for people to use online media to shop. This is of course a great opportunity for platforms online shoppingand online shops to find potential buyers through online digital media. platforms Socialthat are 
often used by consumers to shop online include Instagram, Facebook and marketplaces operating in Indonesia, like a statement Sukaris et al. (2021) that this condition has changed shopping which was originally offline now shifted to online shopping

PayPal research results entitled "Asia Social Commerce Report" in 2018, Facebook became the platform used by business actors in Indonesia, whose value was $92 \%$. Furthermore, business actors chose WhatsApp and Instagram at $76 \%$ and $72 \%$, respectively. Meanwhile, $49 \%$ of business actors choose to use Facebook Messenger to sell (https://databoks.katadata.co.id, 2020).

Social media Facebook as one of the social media that connects everyone has developed into one of the online buying and selling media that is growing rapidly. Besides having access to exchange information very quickly between users, so that more and more online businesses have sprung up on Facebook, especially since the Facebook application added ashopping feature marketplace. Online business activists can take advantage of all the features provided by Facebook for free to promote their products in the form of photo upload features, fanpage group photo tags and also paid advertising features. Free promotions on Facebook for online product promotion are the main attraction foractivists online shop.

The online store in this study is an online store on Facebook. A wide variety of products are offered in the application created by Mark Zuckerberg. Starting from food products, household equipment, sports equipment, vehicles to services are also offered on the Facebook social network. The main reason many online shops sell their products on Facebook is the ease of access and most internet users have a Facebook account. Users sit and play their fingers to access the Facebook site, see the product they are looking for and can ask the seller directly. Meanwhile, the seller only includes photos of the goods being sold along with information in the form of product quality, price, size and can see reviews if entered by the seller. The convenience offered by Facebook social media makes it very easy for sellers and buyers to transact online.

Shopping online on Facebook media in addition to providing benefits for the seller and buyer. Online shopping on Facebook requires a high level of trust from the buyer regarding product quality and payments where there are no guarantees like online platforms shops such as shopee, tokopedia, lazada and others where before the goods are received by the customer, the money from the buyer cannot be disbursed.

When viewed from the background stated and looking at the phenomena that have been stated above, the researcher wants to research the factors of consumer trust, quality and ease of use on consumer buying interest on social media Facebook.

\section{LITERATURE REVIEW}

\section{Social Media and E-Commerce}

Online social networks build communities that bring people together through the internet. In today's information-centered society, internet-based social media and networks are used as tools for online exchange, connection, and communication, enabling users to manage existing relationships while creating new ones (Ryan and Jones, 2009). The creation of these relationships forms an online community where interaction and socialization are the main focus, with members who share common interests and learn about each other by exchanging information (Buss \& Strauss, 2009). This information is often referred to as social media, which is simply the content contained in social networks: namely photos, status updates, videos and links to websites (Elley \& Tilley, 2009).

They also exemplify the combination of social media concepts and networks such as Facebook, Twitter, MySpace, all of which aim to connect groups and individuals such as friends, relatives and business associates. Social networks are becoming more popular than other communication methods such as by telephone, cellular, face-to-face, and e-mail (Gil-or, 2010a). As mentioned above, this paper will look 
specifically at Facebook which is the most visited online social network and has a large number of users (Carlson, 2011; Techtree News Staff, 2008).

Wider access to social media makes it an effective business promotion tool. One of the best ways that online sellers can use to expand market reach is by utilizing social media as a marketing tool in today's digital era. Blogs, Facebook, Twitter, YouTube, and other social media will be very useful for companies to reach potential consumers compared to using conventional media, namely TV, print media, advertisements, leaflets and brochures.

The Facebook community is the user whose members are most relevant for marketing (Castelyn, Mottart \& Rutten, 2009). Through this community, marketers can identify consumer tastes and preferences, which are important in helping to create market segmentation and targeting and positioning strategies (Acar \& Polonsky, 2007; Treadaway). Marketers can derive valuable information on the profiles of community members and from newsfeed statements that users post on their walls and pages (Casteleyn, Mottart, \& Rutten, 2009), this information can then be used for direct marketing.

According to Edelman (2007), today's customers are turning to the use of social networks and more time is spent on online marketing than other marketing channels. Facebook allows companies to reach a larger number of people than being approached via phone calls, emails, or meetings (Luke, 2009). One of the main benefits of social media networks for organizations is that they are lower marketing costs compared to other forms of marketing. With the change in current spending patterns. Low costs can be utilized by business owners to reach out. Low marketing costs with the use of social networks create opportunities for organizations to communicate directly, quickly, and consistently with millions of individual customers (Mize, 2009; Palmer \& Koenig-Lewis, 2009).
There are several reasons why someone makes transactions online, namely, consumers can buy goods at any time without having to go to a store; they get the same product at a lower price by comparing prices in several online stores simultaneously; reduce the pressure when interacting face-to-face with salespeople, can avoid traffic jams, have more variety of products, don't rush into shopping because there are no time limits, and many payment options and so on. These factors can be summarized into four categories, namely convenience, completeness of information, time, and consumer confidence. (Kotler \& Armstrong, 2003).

A sense of security when transacting online is the main thing that consumers need in addition to the price offered and the products offered are able to provide satisfaction for consumers (Saragih and Ramdhany, 2012: 110). In addition to price, the results of the study (Wijaya and Teguh, 2012:110) found that buying interest on social media was influenced by the variables of price, promotion, ease of purchase, and trust.

Judging from the exposure put forward, the researchers wanted to know the influence of consumer trust, quality and convenience factors on consumer buying interest on Facebook social media. The object is consumers who have shopped on social media facebook.

\section{Buying Interest}

Buying interest is part of the attitude component in consumption behavior. Consumers' buying interest can form their choice between several brands that are incorporated in various options, after that they draw conclusions in making purchases on an alternative that they really like or the process that consumers go through to buy goods or services based on various considerations (Pramono, 2012: 136).

Kotler and Keller (2009), "Purchase interest is a reaction generated by the attitude and willingness of consumers to do". For Durianto and Liana (2004: 44), "Purchase 
intention is something that is planned by the buyer regarding what goods and how many items will be purchased for a certain time". Based on the explanation above, it can be concluded that buying interest is the buyer's desire which is reflected in the plan to have a product with a certain brand.

\section{Consumer Trust}

For online customers, carrying out transactions with online shop owners should think about the uncertainty and effects when compared to buying and selling offline. Consumers are given little opportunity to identify the quality of the product and carry out testing of the desired product through the website or Facebook media provided by the online shop owner. When customers make purchases from unknown online shop websites, they cannot identify the quality of the goods and services offered whether they are suitable and reliable or not.

Grabner-Krauter (2002) defines uncertainty in e-commerce as system uncertainty caused by security and technical problems in the system, as well as transaction uncertainty which is explained by unrelated data in the transaction process. Previous research (Doney, Cannon and Mullen..(2003); Eden.(1988); Kim, Silvasailam, Rao.. (2004) proves that trust is defined as something that is appropriate if someone believes, and wants to depend on others" ( Mcknight et al., 1998 p. 474)

Trust For customers, it is very important to reduce doubts about the risks of transacting online. Kathryn and Mary (2002) prove that the risk of e-commerce lies in the trust of buyers and sellers. Trust can balance the level of risk from inseparable e-commerce transactions and reduce the perception of risk.

Schurr and Ozanne (1985), define trust as a promise made by a company and an effort to fulfill promises with customers. Mayer et al (1995), willingness to serve customer needs by the company is a form of trust. So it can be concluded that trust refers to trust in the company's promises to customers and can be trusted and provide mutually beneficial actions, by Following Coleman (1990).

The assumption about the effect can be seen as a person's diagnosis of the positive and negative possibilities that may arise in a transaction or situation. Some transactions have risks that are specific to the transaction itself, including financial exhaustion, data uncertainty, complexity and asymmetry (Kimmery and McCord: 2002). The level of assumption about the effect attached to a change is balanced by the level of confidence. Fukuyama (1995) and Morgan and Hunt (1994) show that confidence can reduce assumptions about effects in transactions.

\section{Product Quality}

The concept of quality has continued to change throughout history, and until now has always been of interest to both scientists and users in the field of management. Once the significance of quality was interpreted as one of the forces, especially in the development of industrial economics in the global market (Feigenbaum, 1982), there are at least 3 things that cause the industry to focus on product quality, in competing in the market since the second world war, technology has allowed few people to produce a product of great quality and at competitive prices, after that the second is the rapid advances in telecommunications and transportation have allowed the transfer of information and products anywhere very quickly, and the third is the barriers to trade in all countries. The world has declined, making it possible to do business anywhere and anytime. (Cortada, 1996) The quality of goods and services based on customer expectations can be categorized into 9 parts, namely:

1. Performance; a product or service that meets customer needs and functions consistently. While the service is a benefit obtained by the customer directly with the principle that cannot be separated. So, performance is an attribute of responsiveness,assurance, and empathy. 
2. Responsiveness; willingness to fulfill customer desires and provide the best for customers which refers to product knowledge and service friendliness to convince customers

3. Empathy; concern for customers related to the appearance or model of the goods offered whether they are in accordance with the description given in the form of facilities, patterns, equipment and communication.

4. Serviceability; facilities provided in the form of post-purchase product maintenance and repair.

5. Features; the function of the same product between similar products that have different characters

6. Reliability; the ability of the product and the proper use of its functions for a certain period of time.

7. Durability; period of use of the product or service.

8. Fitness of use; the product described is in accordance with the information provided, for example a design that does not match the product information provided so that the customer will be disappointed.

9. Conformance; The dimension emphasized by the experts that defines quality is conformance.

\section{Ease}

When someone wants to shop on social media, what is considered for online shoppers is the aspect of ease of use. This aspect of convenience is related to online transaction procedures. Generally, prospective buyers experience difficulties at the beginning of online transactions, and tend to discourage their intentions because of the security aspect and do not know the methods of transacting online.

On the other hand, there are also potential buyers who take the initiative to obtain information about online transaction methods. A good web online shop provides instructions for online transaction methods, ranging from payment methods, as well as features for filling out purchase forms. Ease also makes consumers believe that technology can be easily used, easier to operate and easier to use by social media users. Ease of finding the information presented in the online shop should include data relating to the products and services contained in the online shop.

\section{METHODS}

\section{Conceptual Framework}

The research method in this study is a quantitative method by collecting data using a questionnaire and then processing it using statistical methods. The sample used are consumers who have shopped online on Facebook social media so that a total sample of 211 people who have made online purchases on Facebook social media from 320 filled out questionnaires. The variable used is one dependent variable, namely buying interest and the independent variable is consumer confidence, product quality and convenience. The conceptual framework used can be seen in the chart below:

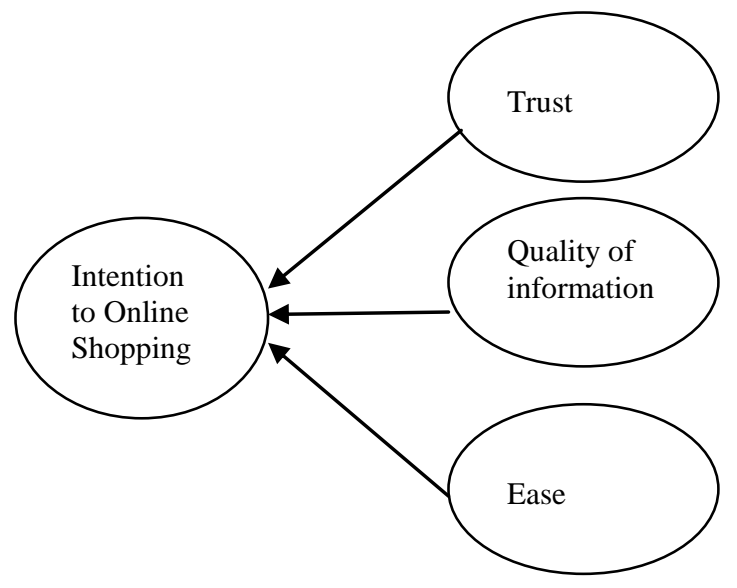

Figure 1: Conceptual Framework

\section{Research Variables}

Research variables are attributes of people, objects, or activities that have certain methods determined by researchers to use and draw conclusions. This study contains two variables, namely the dependent variable and the independent variable.

1. Independent variable (X) 
a. Consumer Confidence (X1) is the level of consumer confidence in the credibility of online sellers.

b. Information Quality (X2) is the customer's perception of the quality of product or service information provided by online sellers.

c. Ease of transaction (X3), namely the level of consumer proficiency in using technology and online shopping applications on Facebook

2. The dependent variable (Y) is online buying interest, namely buyers who make online purchases directly for products or services.

\section{Hypothesis}

1. H1: Consumer trust has a positive effect on online buying interest on Facebook

2. H2: Ease of transaction has a positive effect on online buying interest on Facebook

3. H3: Information quality has a positive effect on online buying interest on Facebook

\section{RESULTS AND DISCUSSION}

The results of the distribution of questionnaires as a description of respondents who have shopped online on social media facebook in the study can be seen in the following table:

Table 1. Description of Respondents

\begin{tabular}{llll} 
Statement & Description & Total & Percentage of \\
& & & \\
\hline \multirow{2}{*}{ Social Media } & Facebook & 211 & $29.9 \%$ \\
& Whatsapp & 261 & $36.96 \%$ \\
& Instagram & 230 & $32.6 \%$ \\
& Twitter & 4 & $0.56 \%$ \\
\hline \multirow{2}{*}{ Gender } & Male & 70 & $33.17 \%$ \\
& Female & 141 & $66.83 \%$ \\
\hline \multirow{2}{*}{ Product } & Accessories & 103 & $20.89 \%$ \\
& Clothes/veil & 153 & $31.03 \%$ \\
& Shoes & 104 & $21.09 \%$ \\
& Cosmetics & 90 & $18.25 \%$ \\
& Electronic & 43 & $8.72 \%$ \\
\hline
\end{tabular}

\begin{tabular}{llll}
\hline Decision to buy & Yourself & 202 & $79.2 \%$ \\
& Parents & 33 & $12.94 \%$ \\
& Siblings & 7 & $2.75 \%$ \\
& friends & 13 & $5.09 \%$ \\
\hline
\end{tabular}

From the table above, it can be concluded that online shopping on Facebook is 29.9\%, which is still below WhatsApp and Instagram at $36.96 \%$ and $32.6 \%$. This shows that online sales activists on Facebook need to improve their performance so that they can increase consumer buying interest to shop online. For gender alone, women are more dominant in online shopping by $66.83 \%$ compared to men. The most purchased products online from the results of this questionnaire were clothing at $31.03 \%$ and the lowest was electronics. This may be due to concerns if buying electronic products that do not meet consumer expectations. Online purchasing decisions on Facebook about $79 \%$ of respondents make purchases based on their own decisions where consumers feel that the goods sold are in accordance with their needs.

\section{Validity and Reliability Test}

The validity test shows the results with the criteria of rarithmetic > rcriticalcritical 0.138 , indicating that the rcount value of the assessment indicator $>0.138$, so that the results of processing research data are declared valid.

The Reliability test resulting that the average Cronbach's alpha value is 0.883 above 0.70 , so the results conclude that all indicators from the research are reliable.

\section{Classical Assumption Test}

The normality test for Asymp. Sig. (2tailed) on all research variables, namely 0 , $210>; 0.05$, thus it can be concluded that the data is normally distributed. Based on the results of the multicollinearity test, the tolerance value is greater than 0.10 , which means that there is no multicollinearity. This is also for the Variance Inflation Factor (VIF) value which the value is less than 10 . So it can be concluded that there is no symptom of 
multicollinearity in this research model. Symptoms of heteroscedasticity did not occur in this study where all variables were not significant below 0.05 , so it can be concluded that this regression model does not contain heteroscedasticity or is homoscedastic. Autocorrelation test was conducted to determine whether there was a correlation between the previous times and obtained the value Durbin Watson of 1.918 and this value was compared with the table DW value. With the amount of data 211 and the value of $\mathrm{dl}=$ $1.738, \mathrm{du}=1.799$ and $\mathrm{k}=3$, the obtained value is $1.738<1.918<4-1.799$, it can be concluded that this regression model is free from autocorrelation problems.

\section{Multiple Regression Analysis}

Table 2. Coefficient of Determination

\begin{tabular}{ccccc}
\hline Model & $\mathrm{R}$ & $\begin{array}{c}\mathrm{R} \\
\text { Square }\end{array}$ & $\begin{array}{c}\text { Adjusted } \\
\text { R Square }\end{array}$ & $\begin{array}{c}\text { Std. Error } \\
\text { of the } \\
\text { Estimate }\end{array}$ \\
\hline 1 & $.779^{\mathrm{a}}$ & .607 & .601 & 1811 \\
\hline
\end{tabular}

a. Predictors: (Constant), X3, X1, X2

b. Dependent Variable: Y

Based on the table above, the value of $\mathrm{R}$ square is 0.607 or $60.7 \%$ which shows that the ability of the independent variable to trust, ease and quality of information can be explained by the dependent variable buying interest of 60.7 percent and the remaining 39.3\% are other factors that are not included. in this study for example risk perception, advertising, promotion and so on. Furthermore, to see how much all the independent variables jointly affect the dependent variable, it is necessary to do a simultaneous significance test ( $F$ test). The following table shows the simultaneous significance test:
Table 3:Simultaneous Significance Test (F-Test)

\begin{tabular}{lrrrrr}
\hline $\begin{array}{l}\text { Mod } \\
\text { el }\end{array}$ & \multicolumn{1}{c}{ SS } & df & MS & F & Sig. \\
\hline MR & $\begin{array}{rrrrr}1047,3 \\
98\end{array}$ & 3 & $\begin{array}{r}349, \\
133\end{array}$ & 106,46 & $000^{\mathrm{b}}$ \\
& & & & \\
\hline $\mathrm{R}$ & 678,80 & 207 & 3,27 & & \\
& 1 & & 9 & & \\
\hline Total & 1726,1 & 210 & & & \\
& 99 & & & & \\
& & & &
\end{tabular}

a. Dependent Variable: Y

b. Predictors: (Constant), X3, X1, X2

Based on the ANOVA test or T-test, the FCount value is 106.468 with a probability of 0.000 ; then the probability is less than alpha 0.05 , it can be concluded that together (simultaneously) all independent variables (x1, $\mathrm{x} 2, \mathrm{x} 3$ ) which are included in the model have a significant effect on the buying interest variable (Y).

Table 3. Multiple Regression Equations Test

\begin{tabular}{|c|c|c|c|c|c|}
\hline \multirow{2}{*}{ Model } & \multicolumn{2}{|c|}{ USC } & $\mathrm{SC}$ & \multirow[t]{2}{*}{$\mathrm{t}$} & \multirow[t]{2}{*}{ Sig. } \\
\hline & B & $\begin{array}{l}\text { Std. } \\
\text { Error }\end{array}$ & Beta & & \\
\hline (Constant) & .917 & .695 & & 1.321 & .188 \\
\hline $\mathrm{X} 1$ & .062 & .375 & .388 & 6,218 & 000 \\
\hline $\mathrm{X} 2$ & .222 & .056 & .245 & 3953 & .000 \\
\hline $\mathrm{X} 3$ & .299 & .081 & .277 & 3.690 & .000 \\
\hline
\end{tabular}

Source: SPSS 2021 test results

Based on table 3 above, the regression results obtained the following results:

$$
\mathrm{Y}=0.917+0.338 \mathrm{X} 1+0.222 \mathrm{X} 2+0.299 \mathrm{X} 3
$$

The Influence of Trust on Interest in Buying Online on Facebook

The trust variable has a positive coefficient of 0.338 and is significant to online buying interest on Facebook. This shows that if 
the buyer is able to provide a sense of trust to the consumer, it will increase buying interest by 0.338 times. The results obtained are proven to be in accordance with hypothesis one, namely trust has a positive effect on online buying interest on Facebook. This is in line with the research of Harris \& Goode (2010) which states that trust has a positive effect on buying interest. Arief \& Farah (2019) also show the same result where trust affects consumer buying interest.

Trust in online stores arises when the online store already has an existence. Consumers will have more confidence in a well-known online store than an emerging online store. In addition, the ability of the online store itself in providing services can also affect consumer confidence. The trust that already exists in a person will lead to a sense of consumer buying interest in online stores. This shows that the higher the level of consumer confidence, the higher the consumer's buying interest.

\section{The Effect of Ease of Transactions on Interest in Buying Online on Facebook}

The ease of transaction variable has a positive coefficient of 0.222 and is significant to online buying interest on Facebook. This shows that if buyers are able to provide convenience in transactions either by transfer or COD to consumers, it will increase buying interest by 0.222 times. The coefficient results obtained prove that the second hypothesis is proven where the ease of transactions has a positive effect on online buying interest on Facebook.

The results of this study are the same as Jajuk's research (2019) that the use of Facebook and the transaction process is very easy and this shows that there is a positive attitude towards the ease of online transactions on Facebook. Therefore, for online sellers on Facebook, so that consumers' interest in buying online will increase if they are given convenience in transactions, for example, for those who do not have an account, they can use the COD system in addition to providing convenience as well as providing a sense of security for consumers.

\section{The effect of information quality on online buying interest on Facebook}

The information quality variable has a positive coefficient of 0.229 and is significant to online buying interest on Facebook. This shows that if online sellers on Facebook can provide accurate and reliable information and the results of previous buyer reviews, it will increase buying interest by 0.338 times. From these results it can be concluded that hypothesis 3 is accepted where the quality of information has a positive effect on online buying interest on Facebook.

The results of this study are in line with the research of Ho \& Wu (1999) which states that the quality of information has a positive effect on buying interest. The better the quality of information on products, payments and so on will increase consumer buying interest to shop online.

\section{CONCLUSIONS}

Based on results and discussion can conclusion; The trust variable has a positive coefficient of 0.338 and is significant to online buying interest on Facebook. This shows that if the buyer is able to provide a sense of trust to the consumer, it will increase buying interest by 0.338 times. The ease of transaction variable has a positive coefficient of 0.222 and is significant to online buying interest on Facebook. This shows that if buyers are able to provide convenience in transactions either by transfer or COD to consumers, it will increase buying interest by 0.222 times. The information quality variable has a positive coefficient of 0.229 and is significant to online buying interest on Facebook. This shows that if online sellers on Facebook can provide accurate and reliable information and the results of previous buyer reviews, it will increase buying interest by 0.338 times.

For Suggestion; 1) Research is still far from perfect, and the variables used are not all 
able to show the use of social media for ecommerce. 2) The variable that can be added for further research is risk perception because from the results of interviews conducted there are doubts from consumers to shop on social media compared to shopping in marketplaces such as Lazada, Tokopedia and Shopee because of a positive attitude where transaction security, product reviews, promotions and convenience in comparing similar products so as to provide a sense of security for consumers. 3) For sellers on Facebook, it is very important to review the goods purchased, both in quality and in the delivery process so that there is a sense of security and it is necessary to add promos and detailed product information so that consumers are sure that the products purchased are in line with their expectations.

\section{REFERENCES}

Bachriansyah, Rizky Amalina, (2011). Analysis of the Effect of Product Quality, Advertising Attractiveness, and Price Perception on Consumer Purchase Interest in Nokia Mobile Phones. http://ep rints.undip.ac.id/. Accessed on 21 April 2015, 10:28 am

Bertha silvia sutejo (2006). "Internet Marketing: New Concepts and Problems in the World of Marketing". Journal of Management, Vol. 6, No. 1.

C, Trihendradi (2009). 7 easy steps to perform statistical analysis using SPSS 17. Yogyakarta: Andi

Ferdinand, Agusty. (2006). Management Research Methodology. CV. Indoprint:: Semarang

Ghozali, Imam. (2001). Multivariate Analysis With SPSS. Semarang: BP UNDIP

Ghozali, Imam. (2006). Advanced Multivariate Analysis with SPSS. Edition I. Semarang: BP UNDIP

Halim, Cipta.(2010). shop smart and open a slang outlet at kaskus. jakarta: PT Elex Media Computindo

Ho, Ching-Fu, and Wen-Hsing Wo, (1999) "Antecedent of Customer Satisfaction on the Internet" Proceeding of the 32nd Hawaii International Conference on System Science.

https://databoks.katadata.co.id/ datapublish/2020/10/21/facebook-

platform-most-diminati-the-business-inindonesia

https://databoks.katadata.co.id/datapublish/2019

/12/03/96-user-internet-di-indonesia-

pernah-gunakan-e-commerce\#

Kaur, Gurpreet. (2016)."Social Media Marketing." Asian Journal of Multidisciplinary Studies 4.7

Putri, Eryta Ayu, (2013). Thesis. Instagram Application as an Online Shop Marketing Communication Media. Veterans National Development University. Surabaya

R.Arief (2019) "Analysis of Perception and Affect of Interest in Buying Online on Facebook Social Media" vol 15 number 1. Safko, Lon, and K. David. "Brake (2009), the Social Media Bible: Tactics, Tools, and Strategies for Business Success. Hoboken."

Schivinski, Bruno, and Dariusz Dabrowski. (2016) "The effect of social media communication on consumer perceptions of brands." Journal of Marketing Communications 22.2): 189-214.

Sukaris, S., Renedi, W., Rizqi, M. A., \& Pristyadi, B. (2021, February). Usage Behavior on Digital Wallet: Perspective of the Theory of Unification of Acceptance and Use of Technology Models. In Journal of Physics: Conference Series (Vol. 1764, No. 1, p. 012071). IOP Publishing.

Sukaris, S., Hartini, S. and Mardhiyah, D. (2019) 'Increasing Electronic Word-ofMouth Activities through Self-Congruity and Tourist Values', International Journal of Innovation, Creativity and Change, 9(10), pp. 162-183. 